\title{
Short-Term Metal/Organic Interface Stability Investigations of Organic Photovoltaic Devices
}

Conference Paper NREL/CP-270-42568

May 2008

\section{Preprint}

M.O. Reese, N. Kopidakis, G. Rumbles, and D.S. Ginley National Renewable Energy Laboratory

A.J. Morfa and M.S. White University of Colorado-Boulder

S.E. Shaheen University of Denver

Presented at the 33rd IEEE Photovoltaic Specialists Conference San Diego, California May 11-16, 2008

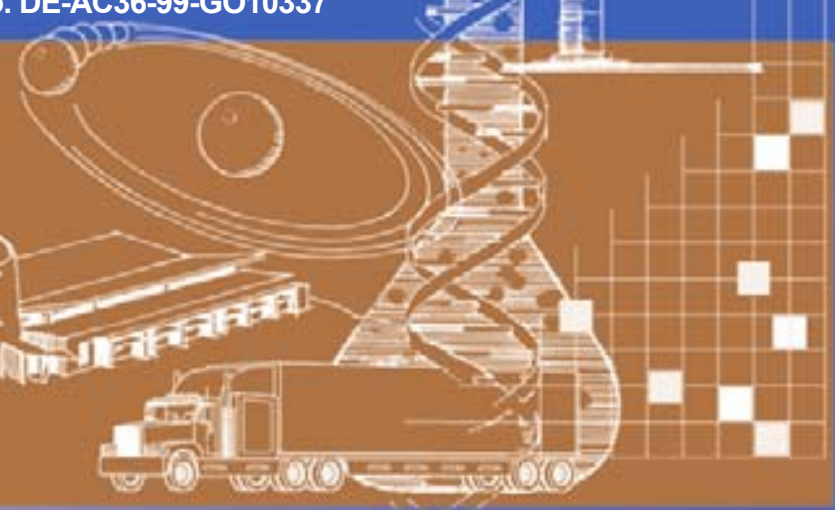




\section{NOTICE}

The submitted manuscript has been offered by an employee of the Midwest Research Institute (MRI), a contractor of the US Government under Contract No. DE-AC36-99G010337. Accordingly, the US Government and MRI retain a nonexclusive royalty-free license to publish or reproduce the published form of this contribution, or allow others to do so, for US Government purposes.

This report was prepared as an account of work sponsored by an agency of the United States government. Neither the United States government nor any agency thereof, nor any of their employees, makes any warranty, express or implied, or assumes any legal liability or responsibility for the accuracy, completeness, or usefulness of any information, apparatus, product, or process disclosed, or represents that its use would not infringe privately owned rights. Reference herein to any specific commercial product, process, or service by trade name, trademark, manufacturer, or otherwise does not necessarily constitute or imply its endorsement, recommendation, or favoring by the United States government or any agency thereof. The views and opinions of authors expressed herein do not necessarily state or reflect those of the United States government or any agency thereof.

Available electronically at http://www.osti.gov/bridge

Available for a processing fee to U.S. Department of Energy and its contractors, in paper, from:

U.S. Department of Energy

Office of Scientific and Technical Information

P.O. Box 62

Oak Ridge, TN 37831-0062

phone: 865.576 .8401

fax: 865.576 .5728

email: mailto:reports@adonis.osti.gov

Available for sale to the public, in paper, from:

U.S. Department of Commerce

National Technical Information Service

5285 Port Royal Road

Springfield, VA 22161

phone: 800.553 .6847

fax: 703.605.6900

email: orders@ntis.fedworld.gov

online ordering: http://www.ntis.gov/ordering.htm 


\title{
Short-term Metal/Organic Interface Stability Investigations of Organic Photovoltaic Devices
}

\author{
Matthew O. Reese, ${ }^{1}$ Anthony J. Morfa, ${ }^{1,2}$ Matthew S. White, ${ }^{1,2}$ Nikos Kopidakis ${ }^{1}$, Sean E. Shaheen, ${ }^{1,3}$ Garry Rumbles, ${ }^{1}$ \\ and David S. Ginley ${ }^{1}$ \\ 1. National Renewable Energy Laboratory, 1617 Cole Boulevard, Golden, Colorado 80401 \\ 2. Department of Physics, University of Colorado, Boulder, Colorado 80309 \\ 3. University of Denver, Physics and Astronomy, Denver, CO 80208, USA
}

\begin{abstract}
As organic photovoltaic (OPV) devices have begun to move toward initial applications, issues of their stability become increasingly of interest. The de facto standard OPV devices are made from a blend of poly(3-hexylthiophene) (P3HT) and $[6,6]-p h e n y l$ C61-butyric acid methyl ester (PCBM); these serve as a test bed for lifetime testing. As delamination, oxidation, and chemical interactions at the metal electrode/organic interface have long been posited as a degradation pathway in organic electronic devices, two short-term experiments were employed to evaluate the stability of this interface in the light and dark. Devices and separate organic surfaces were stable in air over the course of 10's of minutes while in the dark. While devices were stable in air for 100 minutes under constant one sun illumination, the organic surface was not and good devices could not be made on it subsequently
\end{abstract}

\section{INTRODUCTION}

As organic photovoltaics (OPV) have become more efficient, with certified efficiencies as high as $5.4 \%[1]$, issues of their stability become increasingly of interest. Until recently,[2] there has been only scattered data quantifying degradation and exploring the mechanisms in OPV, leaving this area still in its nascent stages. There is not even a clear understanding if the mechanisms are predominately extrinsic or intrinsic. While there are several degradation mechanisms that have already been identified including molecular (thermal and photo-induced) instability, photolytic instability, and interfacial instability (e.g. ITO/PEDOT:PSS), not enough is currently known to determine their relative importance.[3]

This paper addresses one source of degradation in OPV devices: the metal/organic interface. It builds on previously published work from our group, that investigated degradation over the course of days as opposed to minutes.[4] In this previous work, we observed two dominant timescales in the degradation process similar to earlier reports.[5,6] During the rapid initial degradation (over the course of the first hour), devices lost $10 \%$ to more than $30 \%$ of their initial efficiency values.[4] Depending on the conditions the devices were exposed to, after the initial degradation, as little a few percent of the initial efficiency value could be lost over the course of the next ten days. Furthermore, there were indications that the metal/organic interface of the devices studied might have contributed to a significant amount of the overall degradation.

Due to the fact that the short-term degradation was so catastrophic, we decided to revisit this time regime with two simple sets of experiments that would help indicate the role of the metal/organic interface and its stability in air and light. The basic approach was to study the completed device stability vs. the stability of the organic film itself as shown in subsequent devices fabricated from the films.

\section{EXPERIMENTAL APPROACH}

Devices made from a blend of poly(3hexylthiophene) (P3HT) and [6,6]-phenyl C61-butyric acid methyl ester (PCBM) were prepared in the same manner as the previous study.[4] Each sample prepared had room for six typical $\left(0.11 \mathrm{~cm}^{2}\right)$ devices. Three $\mathrm{Ca} / \mathrm{Al}$ electrodes were deposited on each sample, completing three devices per sample. These original devices were measured and used for baseline measurements to normalize later results. Samples were exposed to different conditions, retested, then three more electrodes were deposited and all six devices were retested. All efficiency measurements as well as sample preparations of the active layer and electrode deposition were conducted in a nitrogen glovebox atmosphere. Tungsten halogen lamps (ELH) were used to generate "one sun" conditions (100 $\mathrm{mW} / \mathrm{cm}^{2}$ ), both inside and outside of the glovebox. Samples were kept below $40 \mathrm{C}$ for the experiments with fan cooling.

One set of samples was used for dark measurements, the other for constant one sun illumination. For the dark set, one sample was left in the glovebox, the remaining samples were exposed to air $(21 \pm 1 \mathrm{C}, 26 \pm 1 \%$ relative humidity) for one min., ten min., or $100 \mathrm{~min}$. For the light set, one sample was left in the glovebox under constant one sun exposure for 155 min., the remaining samples were exposed to air ( $\leq 37 \mathrm{C}, 17 \pm 1 \%$ relative humidity) for five min., $25 \mathrm{~min}$., or 100 $\min$.

\begin{tabular}{|c|c|c|c|c|c|}
\hline & Variable & \multicolumn{4}{|c|}{ Time exposed (min.) } \\
\hline $\begin{array}{c}\text { Dark } \\
(21 \pm 1 \mathrm{C}, 26 \pm 1 \% \text { R.H. })\end{array}$ & air & 0 & 1 & 10 & 100 \\
\hline Light & air & 0 & 5 & 25 & 100 \\
\hline ( $\leq 37 \mathrm{C}, 17 \pm 1 \%$ R.H.) & light & 150 & 5 & 25 & 100 \\
\hline
\end{tabular}

Table 1: Experimental matrix for samples. All samples were made with 3 original devices, which were measured before any air exposure. This later served as the baseline for normalization. Dark samples were exposed only to air, whereas light samples were exposed to both air and light to varying degrees. After exposure, the original devices were remeasured, then 3 more devices were completed on each sample by depositing more electrodes and all 6 devices on each sample were tested. 

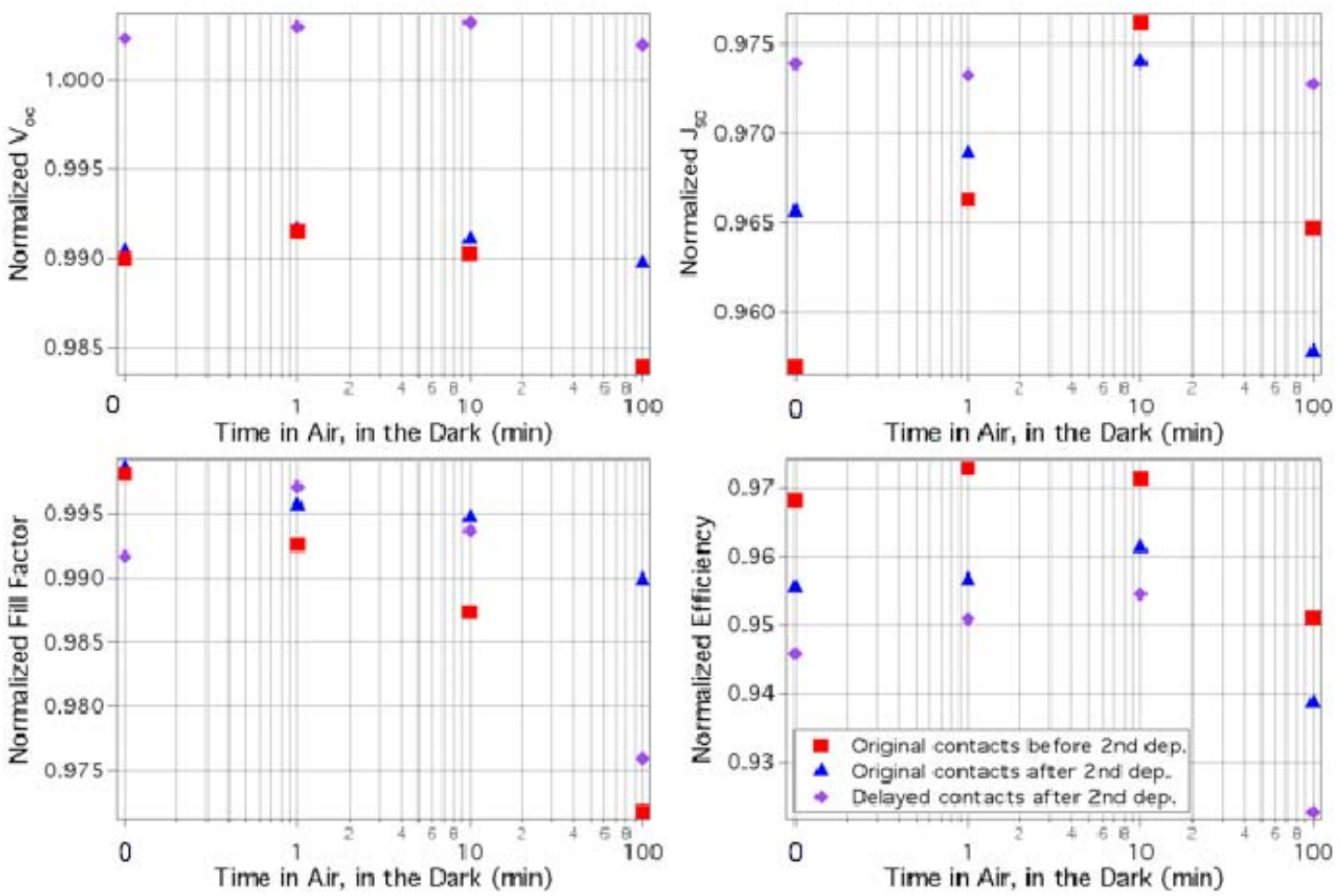

Fig. 1: Samples exposed to air (in the dark) for up to $100 \mathrm{~min}$. The devices, as well as the organic surface are remarkably stable over this timescale. The starting efficiencies for all devices, to which all data is normalized, were roughly $4 \%$.

\section{RESULTS AND DISCUSSION}

\section{Dark, Delayed Contact Experiment}

A summary of device performance for the dark set of experiments is presented in Figure 1. As can be seen, there is no substantial difference between the original or delayed set of devices on each sample exposed to air from zero to ten minutes. For 100 minutes of air exposure, however, there appears to be a little degradation. Measurements were made after exposure to air both before and after the second deposition, to see if the extra vacuum step associated with evaporation might reverse some portion of any observed damage. It is not clear that there was any real effect, from this on the original set of devices.

Here, the greatest reduction in efficiency comes in the short circuit current density $\left(\mathrm{J}_{\mathrm{sc}}\right)$. Larger $\mathrm{J}_{\mathrm{sc}}$ variations were noted in this study, than previously for devices kept in a glovebox under partial illumination for ten days.[4] Across all of the samples, the open circuit voltage $\left(\mathrm{V}_{\mathrm{oc}}\right)$ is the most robust of the critical parameters remaining relatively constant even for devices with delayed contacts. In the previous study, while there was no completely analogous measurement, a $V_{o c}$ reduction of $\sim 4 \%$ was observed for devices illuminated at one sun for $10 \%$ of the time (over a ten day period), and $\sim 2 \%$ reduction for their siblings with delayed contacts.[4]

\section{One Sun Illumination, Delayed Contact Experiments}

A summary of device performance for the constant one sun illumination set of experiments is presented in Figure
2. As can be seen, 150 min. of constant exposure to light (and somewhat elevated temperature) in an inert environment caused more degradation than $100 \mathrm{~min}$. in air, in the dark. In fact, 150 min of light exposure in a glovebox, caused more degradation than either 5 or 25 min. constant illumination in air to the original set of devices. The original devices from the glovebox sample performed very similarly to the original devices from the sample with $100 \mathrm{~min}$. of air and light exposure.

While illumination in or out of a glovebox causes some degradation, the glovebox apparently protects the organic surface from significant degradation when illuminated as seen in the relative performance of the delayed contact devices for the 25 and 100 min. samples.

In this set of experiments, the extra vacuum step again had no significant effect on the devices' overall performance. The greatest reduction in overall performance again comes from changes in $\mathrm{J}_{\mathrm{sc}}$, this time with $28 \%$ and $65 \%$ drops relative to the original baseline devices for $25 \mathrm{~min}$. and $100 \mathrm{~min}$. exposures to air and light.

In the previous study, an almost $10 \%$ reduction in $\mathrm{V}_{\mathrm{oc}}$ was observed after ten days of constant illumination in a glovebox for the original set of devices and about a $4 \%$ reduction for delayed contacts.[4] Here, there is at most a few percent permanent degradation in $\mathrm{V}_{\mathrm{oc}}$, with the extra vacuum step's reviving the devices' $V_{\text {oc. }}$.

In the previous study, after ten days the delayed contact devices exposed to constant illumination and air were dead, while the (unencapsulated) original set had degraded less than $50 \%$ of its original value.[4] Here, we can see that the kinetics for total organic surface degradation in air are on the timescale of maybe a few hours when exposed to one sun (and somewhat elevated temperature). 

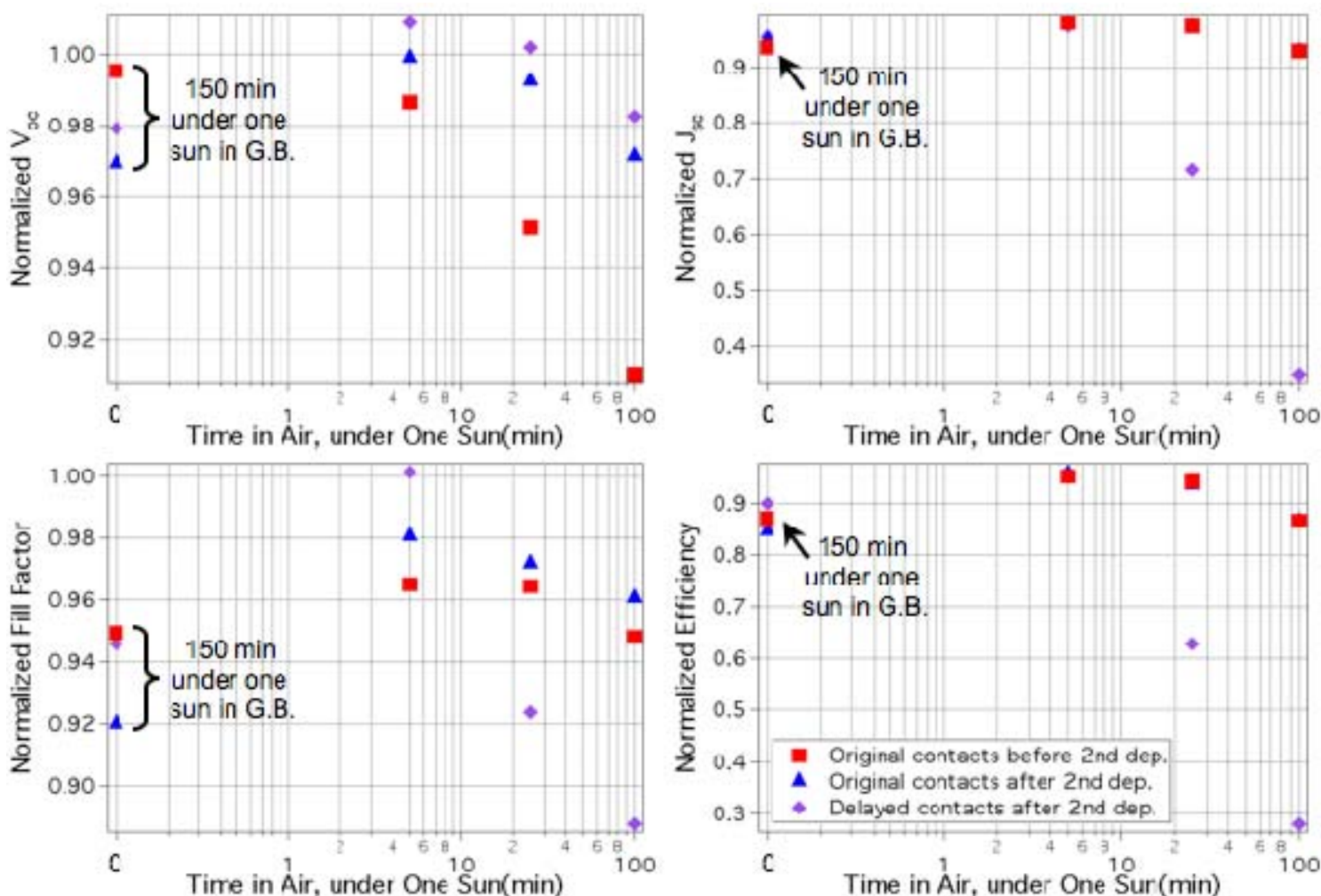

Fig. 2: Samples exposed to air (under one sun constant illumination) for up to 100 minutes. The original devices are more influenced by their exposure to light (and the somewhat elevated temperature) than air. The organic surface, however, degrades quite quickly, with significant degradation apparent after only 25 minutes. The starting efficiencies for all devices, to which all data is normalized, were roughly $4 \%$.

\section{CONCLUSIONS}

This study follows on a previous study, that investigated the stability of metal/organic over the timescale of ten days.[4] The previous study showed that completed devices could continue to operate after days of light and air exposure while the surrounding organic film surface degraded to the point where devices could no longer be made from the films.

Here, devices were not only observed to retain most of their overall efficiency when exposed to short durations of air in the dark, but the surrounding organic film was still capable of being made into devices of similar efficiency. The length of time a completed device is exposed to one sun illumination (at somewhat elevated temperatures), appears to be more important for stability than whether or not a device is exposed to air. The surface of incomplete devices with one sun exposure in air, however, does appear to degrade quite rapidly, with significant degradation setting in after tens of minutes. This may not be surprising as oxidation on the surface may make subsequent device fabrication very difficult. The dry box experiments indicate there may be some intrinsic decomposition in the device.

\section{ACKNOWLEDGEMENTS}

This work was supported by the U.S. Department of Energy under Contract No.DE-AC36-99G010337

\section{REFERENCES}

[1] M. A. Green, K. Emery, D. L. King, Y. Hishikawa, and W. Warta, "Solar Cell Efficiency Tables (Version 31)", Prog. Photovolt: Res. Appl. 16, 2008, pp. 61-67.

[2] F. C. Krebs (Editor), "Degradation and Stability of Polymer and Organic Solar Cells (Special Issue)" Sol. Energy Mater. Sol. Cells 92, 2008, pp. 685-820.

[3] M. Jorgensen, K. Norrman, and F. C. Krebs, "Stability/degradation of polymer solar cells", Sol. Energy Mater. Sol. Cells 92, 2008, pp. pp. 686-714.

[4] M. O. Reese, et al., "Pathways for the degradation of organic photovoltaic P3HT:PCBM based devices", Sol. Energy Mater. Sol. Cells 92, 2008, pp. 746-752.

[5] F. Padinger, et al, "Degradation of bulk heterojunction solar cells operated in an inert gas atmosphere: a systematic study", Synth. Met. 121 (2001) pp. 1605-1606.

[6] F.C. Krebs, et al., "Lifetimes of organic photovoltaics: photochemistry, atmosphere effects and barrier layers in ITOMEHPPV:PCBM-aluminium devices", Sol. Energy Mater. Sol. Cells 86 (2005) pp. 499-516. 


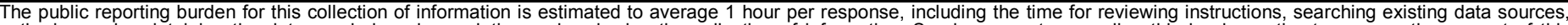

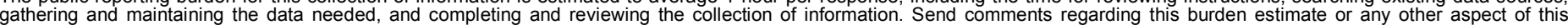

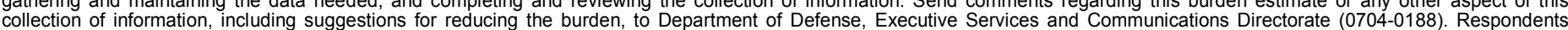

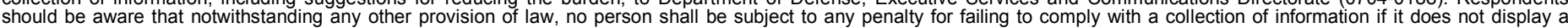

shrrently alid

PLEASE DO NOT RETURN YOUR FORM TO THE ABOVE ORGANIZATION.

\section{REPORT DATE (DD-MM-YYYY) May 2008 \\ 2. REPORT TYPE \\ Conference Paper}

4. TITLE AND SUBTITLE

Short-Term Metal/Organic Interface Stability Investigations of

Organic Photovoltaic Devices: Preprint
3. DATES COVERED (From - To)

11-16 May 2008

5a. CONTRACT NUMBER

DE-AC36-99-G010337

5b. GRANT NUMBER

5c. PROGRAM ELEMENT NUMBER

5d. PROJECT NUMBER

NREL/CP-270-42568

5e. TASK NUMBER

PVA74201

5f. WORK UNIT NUMBER

7. PERFORMING ORGANIZATION NAME(S) AND ADDRESS(ES)

National Renewable Energy Laboratory

1617 Cole Blvd. REPORT NUMBER

Golden, CO 80401-3393

NREL/CP-270-42568

9. SPONSORING/MONITORING AGENCY NAME(S) AND ADDRESS(ES)

10. SPONSOR/MONITOR'S ACRONYM(S) NREL

11. SPONSORING/MONITORING AGENCY REPORT NUMBER

12. DISTRIBUTION AVAILABILITY STATEMENT

National Technical Information Service

U.S. Department of Commerce

5285 Port Royal Road

Springfield, VA 22161

\section{SUPPLEMENTARY NOTES}

\section{ABSTRACT (Maximum 200 Words)}

As organic photovoltaic (OPV) devices have begun to move toward initial applications, issues of their stability become increasingly of interest. The de facto standard OPV devices are made from a blend of poly(3-

hexylthiophene) (P3HT) and [6,6]-phenyl C61-butyric acid methyl ester (PCBM); these serve as a test bed for lifetime testing. As delamination, oxidation, and chemical interactions at the metal electrode/organic interface have long been posited as a degradation pathway in organic electronic devices, two short-term experiments were employed to evaluate the stability of this interface in the light and dark. Devices and separate organic surfaces were stable in air over the course of 10's of minutes while in the dark. While devices were stable in air for 100 minutes under constant one sun illumination, the organic surface was not and good devices could not be made on it subsequently.

15. SUBJECT TERMS

organic photovoltaics; metal/organic interface; electrodes; one sun illumination; intrinsic decomposition; short circuit current density; open circuit voltage;

\begin{tabular}{|l|l|l|l|l|}
\hline \multicolumn{2}{|l|}{ 16. SECURITY CLASSIFICATION OF: } & $\begin{array}{c}\text { 17. } \\
\text { LIMITATION } \\
\text { OF ABSTRACT }\end{array}$ & $\begin{array}{c}\text { 18. } \\
\text { NUMBER } \\
\text { OF PAGES }\end{array}$ \\
\hline $\begin{array}{l}\text { a. REPORT } \\
\text { Unclassified }\end{array}$ & $\begin{array}{c}\text { b. ABSTRACT } \\
\text { Unclassified }\end{array}$ & $\begin{array}{c}\text { c. THIS PAGE } \\
\text { Unclassified }\end{array}$ & $\begin{array}{c}\text { UL } \\
\end{array}$ &
\end{tabular}

19a. NAME OF RESPONSIBLE PERSON

19b. TELEPHONE NUMBER (Include area code) 